\begin{tabular}{|lcc|}
\hline \multicolumn{3}{|c|}{ How BI.MH (ompares (1966 Production) } \\
& Cars & Commercial \\
& $5,557,000$ & Vehicles \\
GENERAL MoToHS & $3,380,000$ & 934,000 \\
FORD & $2,118,000$ & 765,000 \\
CHRYSLER & $1,219,000$ & 211,000 \\
VOLKSWAGEN & $1,148,000$ & 84,000 \\
FIAT & 788,000 & 66,000 \\
BMC+LEYLAND & & 173,000 \\
& & \\
\hline
\end{tabular}

and safety have also added to the amount of research necessary, but so far the idea of a central research laboratory for the group is no more than talk. The situation in BMH is very similar, although its bodymaking subsidiary, Pressed Steel Fisher, did open a central laboratory some months ago. Like most engineering companies, the motor companies have been slow to catch on to the benefits of large scale research. This is not to say that no research work is done, but rather that it is done in a diffuse way, and probably on too small a scale for such an important industry. In the short term there is little chance that this can be avoided-the immediate need for the new company is for some substantial profits.

\section{No Naked Socialists}

THE Industrial Expansion Bill, heralded by cries of horror from the Confederation of British Industry, was made public last week (HMSO, 2s.). And despite the advance publicity-Mr John Davies, Chairman of the CBI, called the bill "mischievous and absolutely (hildish"-it seems unlikely to allow the Government a very strong hand in private industry. The bill provides in the first place for $f 100$ million to be made available to help private industry in schemes which would benefit the national economy but would not be undertaken without support-the sort of support the Government has already made available to the computer companies, the aircraft companies, and more recently the aluminium smelters. The total amount available could be increased to 150 million if Parliament approved. The effect of the measure will be to allow support of this sort to be given without lengthy legislation; but in each case an industrial investment scheme will be drawn up, approved by the Treasury and finally approved by the House of Commons. The measure is hardly naked socialism, nor is it a licence for what is sometimes called "backdoor nationalization".

There will, for one thing, be no power of compulsion vested in the bill, for only plans agreed between the Government and the company involved will be supported. The various ministries involved in the investment schemes will be advised by a committee to be set up by the Minister of 'Technology, and the bill also empowers the National Research Development Corporation and the Industrial Reorganization Corporation to assist the committee and provide advice of their own. The ministers involved will have to report annually to Parliament on the workings of the scheme.

There is no doubt that the bill enables the Government a measure of discrimination-some companies will undoubtedly be supported while others will have to do without. But this is hardly more than the Government already does through its purchasing function. In the absence of a large space or defence programme, it is argued, purchasing power alone is not enough to support the industries which need support. Hence the bill, which seeks to do in a more direct way what is achieved by space and defence programmes in the United States. Whether the attempt will be successful is uncertain - the intervention of government in private industry has not always been well judgedbut even the CBI would hardly claim, for example, that Britain would now have a viable computer industry without Government support at crucial moments in the past.

The bill also provides for a number of measures which had already been announced. Among them is the loan to Cunard of $f^{24}$ million to complete the Queen Elizabeth $\Pi$, and the increase of the borrowing power of the NRDC to $\& 50$ million. The Shipbuilding Industry Board is to be provided with an additional $£ 15$ million, and $£ 1$ million is set aside for the purchase of the Beagle Aircraft Company.

\section{Last Word on Torrey Canyon}

Ten months after the incident, yet another report on the Torrey Canyon disaster has been preparedthis time by the committee of scientists convened by the Chief Scientific Adviser to the British Government, Sir Solly Zuckerman. Readers will be forgiven for asking whether they have heard it all before. Admit tedly the information is clearly presented and very detailed, but there will be many who wonder why it has taken the committee so long to report.

The object is to collect the lessons learnt during the aftermath of the Torrey Canyon incident and to examine the measures to be taken in future, but this also has a familiar ring about it (see Nature, 216, 533; 1967). As outlined in the report, the incident was tackled in six parts: how to deal with the oil remaining in the ship, how to dispose of oil on the sea, how to prevent oil reaching the coastline, how to treat beaches which might be contaminated, how to reduce dangers to marine life and how to co-ordinate the efforts of other bodies dealing with the threat to wild life.

The sequence of events and counter-measures is familiar enough, but it is interesting to note that methods for reducing pollution which were considered impractical in Great Britain were in fact used in France. For example, the French successfully sank oil with powdercd chalk in the deep waters of the Bay of Biscay. where there seems to have been no damage to fisheries. Despite the heavy and continuous contamination of the coast of Brittany, detergent was not used and consequently there was far less damage to the flora and fauna.

What are the lessons learnt from the disaster? At the top of the committee's list is the fact that most of the decisions taken during the crisis had a scientific or technical basis. It suggests therefore that if there is ever another disaster on a similar scale, a team of scientists should again be appointed to co-ordinate scientific advice. Another recommendation is that every effort should be made to salvage a grounded vessel, and that the cargo should be removed by pumping wherever possible. Failing that, and if environmental conditions permit, the ship should be set on fire after opening the tanks, if necessary by bombing. The committee hopes that much of the research work which 
needs to be undertaken could be done on an international collaborative basis, perhaps co-ordinated through the Intergovernmental Maritime Consultative Organization.

Research is considered to be necessary into means of speedy transfer of the cargo from a stranded vessel and methods of firing oil in a stranded tanker and on the sea surface. The committee also recognizes the need to develop more effective but less toxic detergents and to investigate the effects of natural factors in the movement, dispersal and destruction of oil at sea, as well as of the factors determining the stability and formation of different types of oil-water emulsion. Other enquiries, it maintains, should be directed to the disposal of oil by sinking with high density material. The possibility of developing cheap, effective and floating oil-absorbent material and methods of collecting the oil-soaked material in open seas also needs to be examined. Gelling agents are at present expensive and cheaper ones need therefore to be developed. Furthermore, suitable coastal tankers equipped to spray detergent and to ensure that it is mixed with the oil are also desirable. Cheap and effective booms, primarily for protecting harbours and inlets, are not yet available but could prove useful if improved, while mechanical methods for removing oil from beaches and rocks could be reinforced by burning and steam cleaning-the latter having been used successfully in France. Finally, the committee maintains that further research is needed into the effect of oil and detergent on fish and other marine life, sea birds and coastal vegetation.

\section{Too Much Steel}

STEEL production capacity is considerably greater than the demand for it in OECD countries. This observation is made in the recently published OECD review of the iron and steel industries in member countries (The Iron and Steel Industry in 1966 and Trends in 1967 ; OECD, 21s.).

Overcapacity in the steel industry has been a source of increasing concern since 1958 and in Europe in 1966 production of steel was 20 million tons below capacity. This imbalance between supply and demand has had destructive consequences. To maintain large production runs manufacturers have been forced to set export prices at low levels, which has in turn affected domestic prices in many countries. The downward pressure on prices has diminished profits and the ability to maintain a level of essential investment has been seriously impaired.

WORLD PRODUCTION OF STEEL, MULLION TONS

\begin{tabular}{lrrr} 
& 1965 & 1966 & $\begin{array}{c}\text { Per cent } \\
\text { change }\end{array}$ \\
ECSC & $86 \cdot 0$ & $85 \cdot 1$ & $-1 \cdot 0$ \\
UK & $27 \cdot 4$ & $24 \cdot 7$ & $-10 \cdot 0$ \\
OECD_Europe & $127 \cdot 2$ & $124 \cdot 3$ & $-2 \cdot 3$ \\
Canada & $9 \cdot 1$ & $9 \cdot 1$ & $0 \cdot 0$ \\
United States & $119 \cdot 3$ & $121 \cdot 7$ & $+2 \cdot 0$ \\
Japan & $41 \cdot 2$ & $47 \cdot 8$ & $+16 \cdot 1$ \\
\hline OECD total & $296 \cdot 8$ & $302 \cdot 9$ & $+2 \cdot 0$ \\
\hline USSR & $91 \cdot 0$ & $96 \cdot 9$ & $+6 \cdot 5$ \\
Other countries (excluding China) & $56 \cdot 1$ & $60 \cdot 1$ & $+7 \cdot 1$ \\
\hline World (excluding China) & $443 \cdot 9$ & 459.9 & $+\mathbf{3} \cdot 6$
\end{tabular}

World production of steel continued to increase in 1966 but in Europe showed a small decline. Japan is the only large producer whose iron and steel industry experienced a significant increase in production. In the first half of 1967 output in the OECD area continued at about the same rate as that recorded for 1966; the upward trend continued in Japan, but the decrease in the United Kingdom and Germany showed signs of levelling out.

Two basic trends discernible in the international trade in steel are, first, a levelling off or even a decrease in exports to developing countries, and, second, an increase in trade between industrialized countries. Developing countries not only lack the foreign exchange to import steel but in many cases are supporting indigenous industries. The increasing volume of trade between industrialized countries is caused partly by the need to make good shortfalls in production in the countries concerned, and partly by geographical factors, price differences and such competitive conditions as quality, delivery and after-sales service.

Investment expenditure in 1966 again reached high levels in Canada, the United States and Japan, but in Europe was lower than previous years. (In the United Kingdom, at least, the impending nationalization of the industry was probably one of the factors inhibiting investment.) Investment in Europe was usually devoted to modernization and short-term improvements in productivity. The report concludes on the melancholy note that the chronic overcapacity in the steel industry seems likely to continue for many years to come. International efforts to avoid or even alleviate the effects of overcapacity have been unsuccessful. Instead, individual countries have increasingly preferred to take steps to safeguard their own iron and steel industries.

\section{Aluminium from Coal}

The British Government's plan to sell electricity cheaply to aluminium smelters in the hope of starting a new industry in Britain seems not to be going exactly as Mr Wilson intended. Alcan, an aluminium company based in Canada, has decided that it would prefer to buy its coal cheaply and build its own power station. The Government's intention was that the smelters should share the output of a large nuclear power station with the electricity boards, after paying a capital sum equivalent to the amount of electricity the smelter would need. Alcan has lent credence to the National Coal Board's claim that it is still possible to generate electricity more cheaply with coal than with nuclear power, and has at the same time given the electricity boards the uneasy feeling that Alcan is getting better terms than they are. Neither the coal board nor Alcan is revealing the price agreed for the coal, but it will be supplied in substantial amounts1 million tons a year when the smelter is operating fully.

The Coal Board has also had discussions with another aluminium company, Alusuisse, which announced some weeks ago that it was interested in tendering for a smelter. So far these seem only to have been tentative, and no decision has been reached. But, from the point of view of the aluminium companies, there is much to be said for building a small power station sufficient only for their own needs. This spares them the need to satisfy the stringent demands of the generating 